\title{
PENINGKATAN KUALITAS BERMAIN PERAN SISWA KELAS VIII SMP 1 TEPUS DENGAN TEKNIK LEARNING GAME
}

\author{
Sutrisno, Haryadi \\ SMP Negeri 1 Sleman, Universitas Negeri Yogyakarta \\ sutrisnopakem@yahoo.co.id,prof_haryadi @yahoo.co.id
}

\begin{abstract}
Abstrak
Penelitian ini bertujuan untuk mendeskripsikan peningkatan kualitas proses dan hasil pembelajaran bermain peran siswa kelas VIII SMP dengan menggunakan teknik Learning Game. Game yang digunakan adalah permainan Joko Tingkir dan permainan Tebak Peran. Penelitian ini merupakan penelitian tindakan kelas (PTK). Guru bertindak sebagai peneliti yang bekerja sama dengan kolaborator, yakni guru Bahasa Indonesia dan Kepala Sekolah SMP 1 Tepus. Subjek penelitian yang dikenai tindakan adalah siswa kelas VIIIA SMP 1 Tepus Gunungkidul, DIY, tahun ajaran 2011/2012 yang berjumlah 34 siswa. Penelitian ini terdiri atas dua siklus. Setiap siklus dibagi menjadi tiga kali pertemuan. Prosedur pelaksanaan setiap siklus terdiri atas empat tahap, yakni perencanaan, pelaksanaan tindakan, pengamatan, dan refleksi. Teknik pengumpulan data yang digunakan adalah angket, wawancara, pengamatan, dan pencermatan dokumen. Analisis dilakukan dengan teknik deskriptif kualitatif yang didukung oleh data kuantitatif. Hasil penelitian menunjukkan bahwa dengan teknik Learning Game dalam pembelajaran bermain peran, kualitas proses dan hasil pembelajaran meningkat. Peningkatan kualitas proses pembelajaran meliputi aspek interaksi dan komunikasi dalam pembelajaran, kerja sama dalam kelompok, dan keseriusan dalam mengikuti pembelajaran. Adapun peningkatan kualitas hasil pembelajaran meliputi kemampuan vokal, intonasi, ekspresi, dan gestur. Keempat kemampuan tersebut masing-masing mengalami peningkatan nilai rata-rata lebih dari $25 \%$. Hal ini sesuai dengan kriteria keberhasilan tindakan yang ditetapkan.
\end{abstract}

Kata Kunci: bermain peran, teknik Learning Game

\begin{abstract}
This study aims to describe the improvement of the quality of the role playing learning process and learning outcomes for the eighth grade junior high school students by using Learning Game technique. Games used are the game of Joko Tingkir and Guess the Action. This research is a classroom action research study (CAR). The teacher acted as a researcher and worked with two collaborators are Indonesian teacher and Headmaster of Junior High School 1 Tepus. The subject of research was Class VIIIA at Junior High School 1 Tepus, Gunungkidul, 2011/2012 school year, which had 34 students. This research consisted of two cycles. Each cycle was divided into three meeting. Each cycle consisted of four stages, namely planning, acting, observing, and reflecting. Data collection techniques used were questionnaires, interviews, observations, and analyzing document. The analysis was done by using a qualitative descriptive supported by quantitative data. The results of this study show that the Learning Game technique in role play learning can improve the quality of learning process and outcomes. The improvement of the learning process quality involves three aspects i.e. (1) interaction and communication in learning, (2) cooperation in groups, and (3) the seriousness in learning. The improvement of learning quality outcomes are the vocal ability, intonation, expression, and gesture. The four abilities increase up to more than $25 \%$ from the average score. This result is suitable with the $25 \%$ target criteria that is stated in this research.
\end{abstract}

Keywords: role playing, Learning Game techniques 


\section{PENDAHULUAN}

Bermain peran atau bermain drama dapat disejajarkan dengan bermain film sinetron. Meskipun memiliki kekhasan tersendiri, ketiganya memiliki kesamaan, yakni adanya teks cerita, dialog, setting, musik, dan sebagainya (Dewojati, 2010, p.29). Oleh karena itu, bekal kemampuan yang dibutuhkan pun relatif sama. Pemain drama berpotensi mengembangkan kemampuannya secara profesional menjadi artis sinetron ataupun artis film. Demikian juga sebaliknya, artis sinetron/film berpotensi mengembangkan kemampuannya menjadi pemain drama yang profesional.

Kenyataan membuktikan bahwa tidak sedikit orang yang berkeinginan untuk menjadi artis film atau sinetron. Hal ini dapat dilihat dari banyaknya pendaftar yang mengikuti audisi pemilihan calon pemeran dalam sinetron ataupun film tertentu. Sebagai contoh, dalam kompas.com Eko Hendrawan Sofyan menulis berita bahwa pendaftar bintang film dalam film Ketika Cinta Bertasbih yang proses audisinya dilangsungkan di sembilan kota mencapai lebih dari lima ratus orang. Selain itu, Republika Online, Kamis, 24 Desember 2009 juga memuat informasi pendaftaran menjadi aktor dan aktris film Dalam Mihrab Cinta. Tulisan itu berjudul "Casting Terbuka Film Dalam Mihrab Cinta". Dua contoh berita tersebut adalah bukti adanya fenomena baru dalam dunia perfilman di Indonesia. Melalui audisi, orang dapat merealisasikan keinginannya menjadi seorang artis. Dengan terampil bermain peran, seseorang akan lebih mudah untuk dapat lulus dalam audisi menjadi bintang film atau sinetron. Dengan demikian, keterampilan bermain peran mestinya menarik untuk dipelajari.

Berdasarkan fenomena tersebut, perlu kiranya ditumbuhkan seni bermain peran di sekolah-sekolah. Munculnya kegiatan seni bermain peran di sekolah diharapkan dapat melahirkan dramawan-dramawan muda yang penuh idealisme yang mampu menyemarakkan dunia perteateran di Indonesia. Di samping itu, kegiatan seni bermain peran di sekolah diharapkan dapat bermanfaat memberikan bekal kecakapan hidup bagi peserta didik untuk dapat dikembangkan secara profesional.

Endraswara (2003, p.251) menyatakan bahwa bermain drama pada dasarnya sangat penting untuk membangun citra kemanusiaan. Melalui bermain drama, kemanusiaan seseorang terbangun dan hidup. Manusia menjadi paham akan diri sendiri, lingkungan, Tuhan, dan alam semesta. Pernyataan tersebut sejalan dengan pendapat Rahmanto (1988, p.89) yang mengatakan bahwa dengan menghayati berbagai macam peran, para siswa akan memiliki wawasan yang lebih luas tentang hidup dan kehidupan yang dihadapi.

Drama juga dikatakan sebagai sebuah kegiatan bersama dan kooperatif yang membangun imajinasi secara individual maupun kelompok. $\mathrm{Hal}$ ini sesuai dengan pernyataan Baldwin and Fleming (2003, p.6) sebagai berikut.

Drama is a shared and co-operative activity which fires the individual and collective imagination. This can be channelled into forms of artistic expression, which may be written or spoken, individually or collectively expressed.

Untuk menjadi pemain drama yang bisa mendidik sekaligus menghibur penonton, diperlukan bekal dan latihan secara sungguh-sungguh. Salah satu ajang pembekalan dan pelatihan adalah pembelajaran di kelas. Untuk itu, pembelajaran bermain peran seharusnya dilaksanakan oleh siswa dan guru secara sungguhsungguh.

Kenyataan yang terjadi dalam pembelajaran drama atau bermain peran di SMP 1 Tepus menunjukkan bahwa siswa belum bersungguhsungguh jika harus tampil bermain peran di kelas. Berdasarkan hasil pengamatan pratindakan, siswa kurang bergairah atau kurang bersemangat dalam mengikuti pembelajaran. Akibatnya, kompetensi siswa dalam bermain peran belum dapat dikatakan baik. Sebagian besar siswa tampil dengan vokal, intonasi, gestur, dan ekspresi yang kurang sesuai dengan karakter tokoh yang diperankannya. Sebagian siswa tampak tidak serius karena masih sering tersenyumsenyum sendiri ketika sedang ber-acting. Bahkan, ada beberapa siswa yang hanya diam, tidak mau terlibat dalam pembelajaran. Selain itu, berdasarkan hasil wawancara dengan siswa, diperoleh data bahwa siswa merasa kesulitan dalam bermain peran. Siswa merasa tidak percaya diri, enggan, malu, dan terbebani jika diminta untuk bermain peran.

Berdasarkan hasil refleksi, guru menyadari bahwa munculnya berbagai permasalahan disebabkan oleh ketidaktepatan guru dalam memilih metode dan teknik pembelajaran. Selama ini, guru menerapkan teknik penugasan langsung. Teknik yang digunakan guru selama ini belum dapat membantu meningkatkan pema- 
haman dan keterampilan siswa dalam bermain peran. Padahal, peran guru sangatlah penting. Zamroni (2003, p.74) mengatakan bahwa gurulah pemegang peran penting dalam proses belajar-mengajar. Guru adalah kreator pembelajaran. Setelah mengkaji pendapat tersebut dan melakukan refleksi, penulis menyimpulkan bahwa guru perlu mengubah teknik pembelajaran. Teknik pembelajaran yang dipandang mampu meningkatkan kualitas proses dan hasil pembelajaran bermain peran adalah teknik learning game. Siswa SMP yang berusia praremaja mempunyai karakteristik suka bermain. Hal itu sesuai dengan pendapat Monks et al. (1992, p.128) yang mengatakan bahwa anak dan permainan merupakan dua pengertian yang hampir tidak dapat dipisahkan satu sama lain. Selain itu, learning game juga sesuai dengan karakteristik kompetensi dasar bermain peran yang merupakan kompetensi performansi.

Alasan yang memperkuat dipilihnya learning game sebagai teknik pembelajaran bermain peran adalah pendapat Hall dalam Meier (2005, p.206) yang menyatakan bahwa salah satu kesalahan terbesar pendidikan modern adalah overstructuring yang tidak membolehkan bermain di setiap titik pada proses pendidikan. Teknik learning game dipilih sebagai jawaban atas pendapat tersebut. Selain itu, pada bagian lain Monks et al (1992, p.138) juga menyatakan bahwa penelitian mengenai permainan pada anak-anak membuktikan bahwa permainan dapat memajukan aspek-aspek perkembangan seperti motorik, kreativitas, kecakapan-kecakapan sosial, kognitif, dan perkembangan motivasional dan emosional.

Learning game disebut juga permainan belajar. Teknik learning game adalah teknik belajar yang menggunakan permainan sebagai sarana untuk mencapai tujuan, yaitu meningkatkan pembelajaran (Meier, 2005, pp.206-207). Dari konsep tersebut, dapat dipahami bahwa melalui permainan, diharapkan suasana pembelajaran menjadi suasana yang menyenangkan tanpa kehilangan esensi belajar. Learning game juga diharapkan dapat meningkatkan kreativitas siswa dalam belajar bermain peran.

Teknik learning game yang diterapkan dalam pembelajaran bermain peran adalah permainan Joko Tingkir dan Tebak Peran. Permainan Joko Tingkir merupakan permainan sejenis dengan "hom-ping-sut" yang biasa digunakan untuk menentukan pemenang di antara dua orang atau dua kelompok. Dalam permainan Joko Tingkir, peran jari diganti dengan peran
Joko, Ayu, dan Banteng. Selanjutnya, kelompok kalah diberi hukuman yang mengarah pada peningkatan keterampilan bermain peran. Adapun permainan Tebak Peran merupakan permainan menebak peran yang diperagakan oleh lawan main. Permainan ini bertujuan untuk meningkatkan interaksi dan komunikasi, kerja sama dalam kelompok, dan keseriusan dalam pembelajaran. Selain itu, permainan ini juga bertujuan untuk meningkatkan kompetensi berekspresi dan menggunakan gestur dalam bermain peran.

Teknik learning game diharapkan mampu mengakomodasi berbagai pendekatan dan teori pembelajaran, seperti pendekatan kontekstual, teori suggestology, model PAIKEM. Pendekatan kontekstual merupakan konsep belajar yang membantu guru mengaitkan antara materi yang diajarkannya dengan situasi dunia nyata siswa dan mendorong siswa membuat hubungan antara pengetahuan yang dimilikinya dengan penerapannya dalam kehidupan mereka sebagai anggota keluarga dan masyarakat (Depdiknas, 2003, p.1).

Brown (2001, p.27) mengemukakan teori suggestopedia dari Lazanov (1979) yang berisi: "...the human brain could process great quantities of material if given the right conditions for learning, among which are a state of relaxation and giving over of control to the teacher." Dari pernyataan tersebut dapat dipahami bahwa menurut teori sugestologi orang dapat memgolah banyak materi belajar jika diberi kondisi belajar yang baik, antara lain suasana rileks dan pemberian perhatian oleh guru.

DePorter dan Hernacki (1999, p.14) juga menggunakan teori suggestopedia Lozanov untuk mengembangkan Quantum Learning. Prinsipnya, dalam teori "suggestopedia" atau "suggestology" sugesti dapat dan pasti mempengaruhi hasil dan situasi belajar. Berbagai teknik dapat digunakan untuk memberikan sugesti positif seperti mendudukkan siswa secara nyaman, pemberian penghargaan, atau pemunculan suasana kegembiraan.

Pada pembelajaran drama dengan teknik learning game, jelaslah bahwa guru memberikan sugesti positif kepada siswa berupa pemunculan suasana kegembiraan melalui bermain. Dalam kegiatan bermain, siswa diharapkan merasa gembira, namun tidak kehilangan esensi belajarnya. Meski dalam suasana bermain, sebenarnya banyak keterampilan bermain peran didapat-kan siswa.

PAIKEM merupakan akronim dari Pembelajaran Aktif, Inspiratif, Inovatif, Kreatif, 
Efektif, dan Menyenangkan. PAIKEM bersifat lebih memberdayakan siswa, tidak gurusenris, dan menyenangkan. PAIKEM menggunakan prinsip-prinsip pembelajaran berbasis kompetensi. Pembelajaran berbasis kompetensi adalah pembelajaran yang dilakukan dengan orientasi pencapaian kompetensi siswa. Hasil akhir pembelajaran adalah meningkatnya kompetensi siswa yang dapat diukur dalam pola sikap, pengetahuan, dan keterampilannya (Kemendiknas, 2011, p.5).

Rumusan masalah dalam penelitian ini adalah (1) Bagaimanakah penerapan teknik learning game dalam pembelajaran bermain peran?; (2) Bagaimanakah peningkatan kualitas proses pembelajaran bermain peran setelah diterapkan teknik learning game?; dan (3) Bagaimanakah peningkatan kualitas hasil pembelajaran bermain peran setelah diterapkan teknik learning game?

Penelitian ini bertujuan mendeskripsikan penerapan teknik learning game dalam pembelajaran bermain peran, mendeskripsikan peningkatan kualitas proses dan hasil pembelajaran bermain peran. Secara teoretis, hasil penelitian ini akan bermanfaat bagi pengembangan teori pembelajaran dan dapat memberikan kontribusi dalam mendesain teknik pembelajaran sastra, khususnya bermain peran. Secara praktis, hasil penelitian ini dapat menumbuhkan minat siswa terhadap salah satu jenis seni pertunjukan yaitu bermain peran. Selain itu, guru memperoleh pengalaman profesional dalam menyusun rancangan dan melaksanakan pembelajaran bermain peran dengan teknik learning game, dan memperoleh pengalaman dalam kegiatan penelitian yang dapat meningkatkan profesionalitasnya. Sekolah akan memperoleh output siswa yang lebih berkualitas dalam bidang bermain peran.

\section{METODE PENELITIAN}

Jenis penelitian ini adalah Penelitian Tindakan Kelas (PTK). Suyanto (Ardiana, 2003, p.4) mengemukakan bahwa PTK merupakan bentuk penelitian yang bersifat reflektif dengan melakukan tindakan-tindakan tertentu agar dapat memperbaiki dan meningkatkan praktik-praktik pembelajaran di kelas secara profesional.

Pada pelaksanaan PTK, guru terus-menerus mengadakan refleksi, merencanakan tindakan, dan melaksanakan tindakan pada tahap berikutnya. Oleh sebab itu, PTK merupakan proses bersiklus.
Desain yang digunakan dalam penelitian ini mengikuti model yang dikemukakan oleh Kemmis dan Taggart. Model tersebut meliputi empat komponen kegiatan dalam setiap siklus, yaitu perencanaan (planning), tindakan (acting), pemantauan (monitoring), dan refleksi (reflecting).

Penelitian ini dilaksanakan di kelas VIII SMP Negeri 1 Tepus. Dipilihnya kelas VIII karena kompetensi bermain peran diajarkan di kelas VIII. Tempat penelitian ini adalah tempat belajar siswa berupa ruang kelas dan alam terbuka di lingkungan sekolah. Waktu penelitian berlangsung pada semester genap tahun pelajaran 2011/2012 antara bulan Februari sampai dengan April 2012. PTK ini berlangsung dalam siklus-siklus. Tiap siklus terdiri atas tiga kali pertemuan. Tiap pertemuan berlangsung selama dua jam pelajaran.

Subjek penelitian tindakan adalah kelas VIIIA dengan jumlah siswa 34 orang yang terdiri atas 15 siswa putra dan 19 siswa putri. Adapun objek penelitian ini adalah (1) proses pembelajaran, dan (2) kompetensi siswa dalam bermain peran. Dalam proses pembelajaran, aspek yang diteliti meliputi (a) interaksi dan komunikasi siswa dalam pembelajaran, (b) kerja sama siswa dalam kelompok, dan (c) keseriusan siswa dalam mengikuti pembela-jaran. Adapun aspek yang diteliti untuk mengetahui kompetensi siswa dalam bermain peran meliputi penggunaan (a) vokal, (b) intonasi, (c) ekspresi, dan (d) gestur.

Jenis tindakan yang dipilih dalam penelitian ini adalah penerapan teknik learning game dalam pembelajaran. Teknik ini dipilih setelah guru yang sekaligus berperan sebagai peneliti berdiskusi dengan kolaborator untuk menyamakan persepsi dan mengidentifikasi permasalahan yang muncul berkaitan dengan pembelajaran bermain peran.

Pelaksanaan tindakan yang direncanakan dalam Siklus I meliputi empat tahap, yakni (1) perencanaan, (2) implementasi tindakan, (3) pengamatan, dan (4) refleksi. Kegiatan perencanaan tindakan meliputi menyusun silabus dan rencana pelaksanaan pembelajaran (RPP), menyiapkan instrumen penelitian, dan menyiapkan sarana dan media yang diperlukan dalam pembelajaran. Implementasi tindakan hakikatnya sama dengan melaksanakan pembelajaran bermain peran dengan menerapkan teknik learning game sesuai dengan skenario pembelajaran dalam RPP. Pengamatan dilakukan terhadap perilaku siswa dalam pembelajaran. Subjek yang diamati 
adalah siswa kelas VIIIA. Objek yang diamati meliputi (1) interaksi dan komunikasi siswa dalam pembelajaran, (2) kerja sama siswa dalam kelompok, dan (3) keseriusan siswa dalam mengikuti pembelajaran. Pengamatan kedua dilakukan terhadap hasil belajar siswa berupa unjuk kerja bermain peran. Objek yang diamati atau dinilai meliputi vokal, intonasi, ekspresi, dan gestur. Pengamatan ketiga dilakukan terhadap segala peristiwa yang terjadi selama pembelajaran yang difokuskan pada temuan-temuan, baik yang bersifat positif maupun negatif. Refleksi merupakan langkah terakhir dalam setiap siklus yang dilakukan setelah pelaksanaan dan pengamatan tindakan. Refleksi merupakan kegiatan merenungkan kembali hal-hal atau kegiatan yang telah dilakukan. Tujuan refleksi adalah menemukan berbagai kelebihan dan kekurangan yang terdapat dalam pembelajaran. Temuan berupa kekurangan akan dimanfaatkan untuk memperbaiki rancangan tindakan pada siklus berikutnya.

Pada Siklus II, tahapan yang dilaksanakan sama dengan Siklus I, yaitu perencanaan, pelaksanaan, pengamatan, dan refleksi. Rancangan pelaksanaan tindakan Siklus II disusun dengan mempertimbangkan temuan-temuan yang ada pada Siklus I.

Teknik pengumpulan data yang digunakan dalam PTK ini adalah teknik observasi, wawancara, pemberian angket, dan analisis dokumen. Observasi dilakukan oleh peneliti dan kolaborator terhadap subjek dan objek penelitian dalam setiap siklus. Teknik wawancara dilakukan pada tiap akhir siklus untuk memperoleh data tentang baik-buruknya proses pembelajaran yang telah berlangsung dan kesulitan-kesulitan yang dialami siswa. Teknik pemberian angket dilakukan untuk memperoleh data tentang minat siswa dalam pembelajaran bermain peran. Teknik analisis dokumen dilakukan terhadap silabus, RPP, buku sumber, foto-foto kegiatan pembelajaran, dan hasil karya siswa berupa naskah bermain peran.

Teknik analisis data yang digunakan adalah teknik analisis data kualitatif dan kuantitatif. Teknik analisis data kualitatif dilakukan dengan: (1) mengumpulkan data (2) membandingkan data dari guru, siswa, dan kolaborator, (3) kategorisasi, (4) inferensi data, dan (5) menyimpulan. Adapun teknik analisis data kuantitatif dilakukan dengan cara membandingkan nilai rerata siswa pada pratindakan dengan pascatindakan.

Indikator keberhasilan dalam penelitian tindakan ini dikelompokkan dalam dua aspek, yaitu indikator keberhasilan proses dan hasil. Proses pembelajaran dikatakan berhasil jika 95\% siswa minimal berkategori baik dalam hal interaksi dan komunikasi dalam pembelajaran, kerja sama dalam kelompok, dan keseriusan dalam mengikuti pembelajaran. Adapun hasil pembelajaran dikatakan berhasil jika terjadi peningkatan sebesar 25\% antara prestasi subjek penelitian sebelum diberikan tindakan dengan sesudah diberikan tindakan. Prestasi tersebut dilihat dari nilai rata-rata kelas yang meliputi aspek vokal, intonasi, ekspresi, dan gestur.

\section{HASIL PENELITIAN DAN PEMBAHASAN}

Ada tiga informasi awal keterampilan siswa dalam bermain peran pratindakan, yaitu minat siswa terhadap bermain peran dan pembelajarannya, hasil pengamatan proses pembelajaran, dan hasil keterampilan siswa dalam praktik bermain peran.

Berdasarkan hasil angket, minat siswa terhadap bermain peran dan pembelajarannya pada pratindakan menunjukkan bahwa secara umum masih rendah. Persentase rata-rata dari sepuluh pertanyaan yang semuanya bersifat positif, hanya ada $1 \%$ yang menjawab sangat setuju dan $31 \%$ setuju. Adapun yang menjawab tidak setuju ada $60 \%$ dan 9\% sangat tidak setuju. Artinya, persentase siswa yang kurang berminat (tidak setuju dan sangat tidak setuju) lebih banyak daripada persentase siswa yang berminat (setuju dan sangat setuju).

Berdasarkan hasil pengamatan proses pembelajaran bermain peran pada pratindakan dapat disimpulkan bahwa peran aktif siswa dalam pembelajaran masih kurang. Hanya $12 \%$ siswa yang berkategori sangat baik dalam berinteraksi dan berkomunikasi selama pembelajaran dan 35\% siswa berkategori baik. Adapun siswa yang berkategori kurang baik ada 53\%. Dengan demikian, siswa yang minimal baik dalam berinteraksi dan berkomunikasi hanya $47 \%$ yang berasal dari $12 \%$ amat baik ditambah $35 \%$ baik. Adapun siswa yang kurang baik dalam berinteraksi dan berkomunikasi ada 53\%.

Nilai keterampilan siswa dalam praktik bermain peran pada pratindakan secara umum masih rendah. Dari keempat komponen penilaian, tidak ada satu pun yang rata-rata pencapaian kompetensinya mencapai kriteria ketuntasan minimal yang telah ditentukan, yaitu 70. Dari segi vokal ketika berdialog dan bermonolog, $26 \%$ siswa vokalnya belum lantang dan belum terdengar secara jelas. Bahkan, 18\% siswa sangat lemah vokalnya. Siswa yang kompetensi 
vokalnya sudah baik berjumlah $56 \%$, yaitu $50 \%$ katagori lantang dan cukup jelas dan 6\% kategori sangat lantang dan sangat jelas. Nilai ratarata pencapaian kompetensi vokal siswa adalah 61.

Pada aspek intonasi, sebagian besar intonasi siswa masih monoton dalam berdialog dan bermonolog. Mereka belum menggunakan intonasi yang tepat ketika bertanya, terkejut, maupun ketika marah. Sejumlah 44\% siswa, kompetensi intonasinya termasuk kategori kurang bervariasi. Siswa yang intonasinya bervariasi dan cukup sesuai dengan karakter tokoh berjumlah 56\%. Tidak satu pun siswa yang intonasinya berkategori sangat bervariasi dan sesuai dengan karakter. Nilai rata-rata kompetensi intonasi siswa adalah 64.

Pada aspek ekspresi, secara umum dapat disimpulkan bahwa kompetensi ekspresi siswa dalam bermain peran pada pratindakan masih rendah. Ada $32 \%$ siswa yang terlihat kurang serius dalam berekspresi. Mimik mereka kurang sesuai dengan karakter. Bahkan, 12\% siswa berada pada kategori paling rendah dalam berekspresi. Siswa yang serius dan mampu berekspresi dengan mimik yang cukup sesuai dengan karakter berjumlah $53 \%$. Hanya ada $3 \%$ siswa yang sangat kompeten dalam berekspresi. Rata-rata pencapaian kompetensi siswa adalah 62 .

Pada aspek gestur 32\% siswa gerak tubuhnya kurang sesuai dengan karakter dan kurang mampu menempatkan diri di panggung. Mereka masih belum berani menggerakkan tangan, kaki, ataupun anggota tubuh yang lain untuk lebih memberi makna pada dialog mau-pun monolog yang diperankannya. Bahkan, 6\% siswa masih sering membelakangi penonton dengan gerakan-gerakan yang tidak sesuai dengan karakter. Ada $62 \%$ siswa yang gerakan tubuhnya sesuai dengan karakter dan cukup mampu menempatkan diri di panggung. Tidak ada satu pun siswa yang menduduki tingkat paling tinggi dalam hal gestur. Rata-rata pencapaian kompetensi siswa adalah 64. Dengan demikian, dapat disimpulkan bahwa rata-rata kompetensi gestur siswa dalam bermain peran pada pratindakan masih rendah.

Nilai rata-rata kelas pada pembelajaran bermain peran pratindakan yang meliputi vokal, intonasi, ekspresi, gestur adalah 62,75. Nilai rata-rata tersebut belum mencapai nilai ketuntasan minimal, yaitu 70 .

\section{Pelaksanaan Tindakan Kelas}

Penelitian tindakan kelas dalam pembelajaran bermain peran dengan teknik learning game ini dilaksanakan dalam dua siklus. Pada Siklus I guru melakukan perencanaan dengan menyusun silabus dan RPP, menyiapkan instrumen penelitian, dan sarana serta media pembelajaran. Pada implementasi tindakan perrtemuan I, kegiatan yang dilakukan adalah: (1) guru melakukan apersepsi dengan bertanya jawab mengenai pengalaman siswa dalam menyaksikan pentas drama atau bermain peran; (2) guru memperkenalkan kompetensi dasar yang akan dipelajari siswa; (3) secara berkelompok, siswa bermain permainan Joko Tingkir; (4) siswa bermain permainan Tebak Peran; (5) secara berkelompok, siswa mempelajari naskah drama yang ditulis sebagai hasil pembelajaran $\mathrm{KD}$ sebelumnya (menulis naskah drama); (6) siswa berdiskusi menentukan pemain dengan karakter masing-masing; dan (7) siswa berlatih bermain peran sesuai dengan karakter yang diperankannya.

Pada pertemuan II kegiatan yang dilakukan adalah: (1) siswa dan guru bertanya jawab tentang karakter tokoh dalam pembelajaran sebelumnya; (2) siswa berkelompok; (3) siswa meneruskan kegiatan berlatih bermain peran; dan (4) siswa melakukan praktik bermain peran secara berkelompok.

Pada pertemuan III, tahap-tahap kegiatan yang dilakukan adalah: (1) siswa dan guru bertanya jawab tentang aksi bermain peran kelompok yang sudah tampil pada pertemuan sebelumnya; (2) siswa berkelompok; dan (3) siswa meneruskan kegiatan praktik bermain peran secara berkelompok.

Pada tahap pengamatan, guru bersama kolaborator melakukan pengamatan dan evaluasi terhadap jalannya perlakuan tindakan. Hasil pengamatan dan evaluasi ini meliputi dampak tindakan terhadap proses dan hasil pembelajaran. Hasil pengamatan proses pembelajaran menunjukkan bahwa secara umum siswa sudah ada keberanian untuk berinteraksi dengan guru maupun dengan siswa lainnya. Interaksi dan komunikasi tersebut mulai terjalin ketika siswa diajak memerankan tokoh "Joko", "Ayu", dan "Banteng" dengan ucapan dan gerakan yang mudah dipraktikkan oleh semua siswa. Kegiatan memerankan tokoh "Joko", "Ayu", dan "Banteng" dapat dilihat pada gambar berikut. 


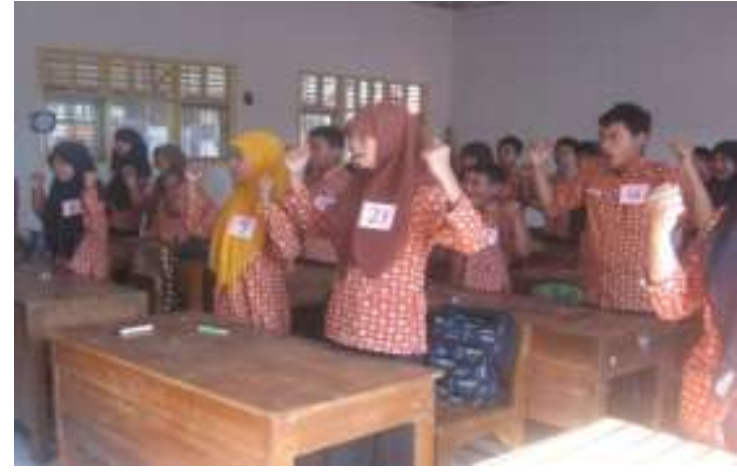

Gambar 1. Kegiatan Memerankan Tokoh "Joko"

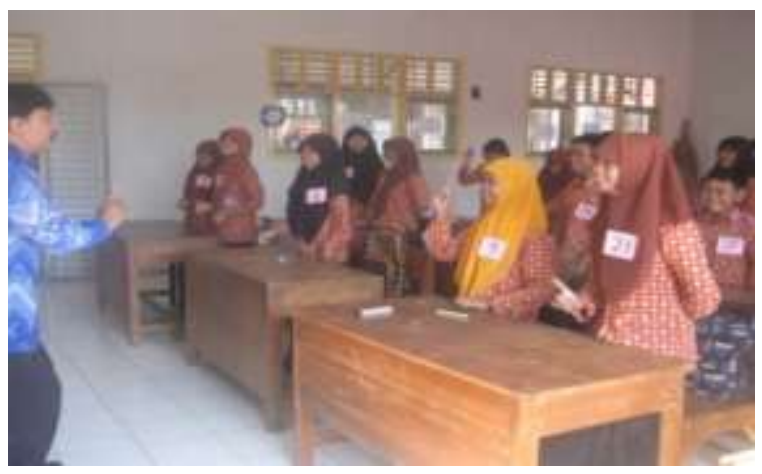

Gambar 2. Kegiatan Memerankan Tokoh "Ayu”

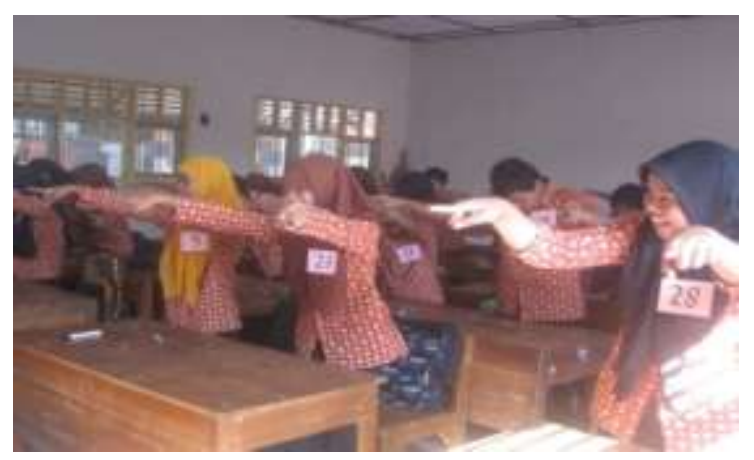

Gambar 3. Kegiatan Memerankan Tokoh "Banteng"

Ketika memperagakan ketiga tokoh tersebut, mereka tampak mulai berani bertanya dan meminta guru untuk mengulangi memberi contoh. Mereka menikmati pembelajaran dengan senang hati. Komunikasi antarsiswa berkembang ketika pembelajaran sampai pada tahap diskusi dan kerja kelompok. Namun demikian, masih ada beberapa siswa yang bersikap pasif. Dari 34 siswa ada $26 \%$ siswa yang berkategori sangat baik dalam berinteraksi dan berkomunikasi selama pembelajaran, $55 \%$ siswa berkategori baik, dan 19\% siswa berkategori kurang baik. Dengan demikian, siswa yang minimal berkategori baik dalam hal interaksi dan komunikasi selama pembelajaran ada $81 \%$.

Dari hasil catatan lapangan kolaborator tentang kerja sama siswa dalam kelompok, dapat disimpulkan bahwa sebagian besar siswa berperan dalam kegiatan diskusi dan kerja kelompok. Menurut pengamatan kolaborator, kerja sama siswa sudah mulai tampak pada waktu bermain Joko Tingkir, yaitu ketika berembug menentukan tokoh yang akan diperankan dalam permainan tersebut. Selain itu, kerja sama siswa juga tampak ketika memberi hukuman dan melaksanakan hukuman. Dari hasil pengamatan secara individu terhadap 34 siswa tentang kerja sama dalam kelompok, diperoleh data bahwa ada $31 \%$ siswa berkategori sangat baik, $63 \%$ siswa berkategori baik, dan $6 \%$ siswa berkategori kurang baik. Dengan demikian, siswa yang berkategori minimal baik dalam hal kerja sama dalam kelompok ada 94\%.

Dari hasil catatan lapangan kolaborator tentang keseriusan siswa dalam mengikuti pembelajaran, dapat disimpulkan bahwa secara umum siswa disiplin dalam mengikuti pembelajaran. Siswa mengikuti pembelajaran dengan cukup serius. Pada tahap bermain, tidak ada seorang siswa pun yang tidak serius mengikuti jalannya permainan Joko Tingkir. Meskipun sambil tertawa-tawa, mereka melaksanakan kegiatan sesuai dengan perintah guru. Demikian pula ketika siswa melakukan permainan Tebak Peran. Semua kelompok memperagakan peran yang ditentukan dengan serius. Kelompok lain menebak peran yang diperagakan tersebut. Akan tetapi, ketika sampai tahap kerja kelompok, masih ada beberapa siswa yang melakukan aktivitas lain di luar pembelajaran. Dari hasil pengamatan individu terhadap 34 siswa tentang keseriusan mengikuti pembelajaran diperoleh data bahwa $45 \%$ siswa berkategori sangat baik, $43 \%$ siswa berkategori baik, dan $12 \%$ siswa berkategori kurang baik. Dengan demikian, siswa yang minimal berkategori baik dalam hal keseriusan mengikuti pelajaran ada $88 \%$.

Dari data tersebut dapat disimpulkan bahwa kualitas proses pembelajaran bermain peran pada Siklus I masih belum optimal. Baru ada $81 \%$ siswa yang berkategori baik dan amat baik dalam berinteraksi dan berkomunikasi dalam pembelajaran. Pada aspek kerja sama dalam kelompok, ada $94 \%$ siswa yang berkategori baik dan amat baik. Pada aspek keseriusan dalam mengikuti pembelajaran, ada $88 \%$ siswa yang berkategori baik dan amat baik. Pencapaian keberhasilan proses ketiga aspek tersebut masih di bawah kriteria keberhasilan dalam penelitian ini, yaitu 95\% siswa minimal berkategori baik.

Praktik bermain peran dilakukan selama dua kali pertemuan, yakni pada pertemuan ke- 
dua dan pertemuan ketiga. Tiap-tiap kelompok berunjuk kerja bermain peran dengan menggunakan naskah yang ditulis mereka sendiri. Pada pertemuan kedua, dua kelompok menampilkan naskah yang berjudul "Wiro dan Sableng $\mathrm{Si}$ Raja Gombal" dan "Bantuan Buku Bekas". Lima kelompok lainnya tampil pada pertemuan ketiga dengan naskah yang berjudul "Kejujuran adalah Awal Kesuksesan", "Akibat Perbuatan Syirik", "Akibat Sombong", "Wewe Pencuri Kambing", dan "Tangisan Seorang Sahabat".

Pada aspek vokal, ada 56\% siswa yang kategori vokalnya lantang dan cukup jelas. Bahkan, 20\% siswa vokalnya sangat lantang dan sangat jelas. Tokoh "Wiro", "Sableng", "Jarwo", "Gendis", "Virgo", "Tara", "Silla", "Jack", "Paidi", "Sutopo", "Sakinah", "Paijo", "Mbah Tarjo", dan "Ningsih" mampu berdialog maupun bermonolog dengan vokal yang jelas dan lantang sesuai dengan karakter tokoh yang diperankannya. Namun demikian, masih ada $24 \%$ siswa yang vokalnya lemah dan kurang jelas ketika berdialog maupun bermonolog. Rata-rata nilai pencapaian kompetensi vokal siswa adalah 74,26.

Pada aspek intonasi, sebanyak $64 \%$ siswa telah mampu menggunakan intonasi yang bervariasi dan cukup sesuai dengan karakter ketika berdialog maupun bermonolog. Bahkan, delapan siswa (24\%) intonasinya sangat bervariasi dan sesuai dengan karakter. Siswa tersebut memerankan tokoh "Silla" dalam lakon "Bantuan Buku Bekas", tokoh "Sableng" dalam "Wiro dan Sableng si Raja Gombal", tokoh "Gendis" dan "Jarwo" dalam "Wewe Pencuri Kambing", tokoh "Sutopo" dan "Paeno" dalam "Akibat Sombong", tokoh "Mbah Tarjo" dan "Sakinah" dalam "Akibat Perbuatan Syirik". Mereka mampu menggunakan intonasi yang tepat ketika bertanya, terkejut, maupun ketika marah. Namun demikian, masih ada $12 \%$ siswa yang intonasinya datar-datar saja atau kurang bervariasi sehingga dialog maupun monolog yang dilakukannya terasa hambar. Nilai rata-rata pencapaian kompetensi intonasi siswa adalah 77,94.

Pada aspek ekspresi, ada 64\% siswa yang terlihat serius dalam berekspresi. Mimik mereka cukup sesuai dengan karakter. Bahkan, $18 \%$ siswa mampu berekspresi dengan mimik yang sangat sesuai dengan karakter. Dari hasil pengamatan diperoleh data mengenai berbagai ekspresi tokoh-tokoh tersebut. Tokoh yang paling ekspresif menurut catatan kolaborator adalah tokoh yang memerankan Mbah Dukun Tarjo. Peran "Mbah Dukun Tarjo" dalam lakon "Aki- bat Perbuatan Syirik" dapat dilihat pada gambar berikut.

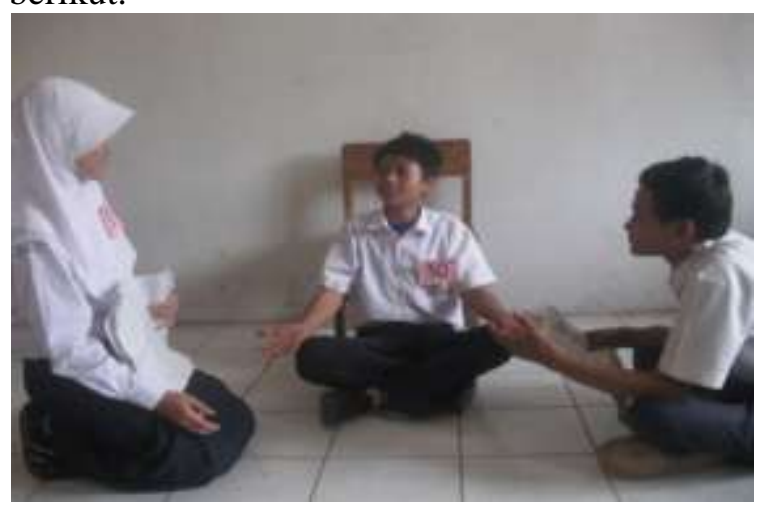

Gambar 4. Acting "Mbah Dukun Tarjo" (tengah)

Di satu sisi, masih ada $18 \%$ siswa yang kurang serius dalam berekspresi. Ekspresi marah, sedih, dan ketakutan seharusnya dilakukan dengan serius, namun dilakukannya sambil tersenyum-senyum. Rata-rata pencapaian kompetensi siswa dalam hal ekspresi adalah 75 .

Pada aspek gestur, tidak ada satu pun siswa yang sering membelakangi penonton ketika sedang berperan di panggung. Namun, masih ada $12 \%$ siswa yang gerak tubuhnya kurang sesuai dengan karakter. Mereka kurang mampu menempatkan diri di panggung, belum bisa memanfaatkan panggung untuk bergerakgerak dari satu sisi ke sisi lain. Mereka juga belum berani menggerakkan tangan, kaki, ataupun anggota tubuh yang lain untuk lebih memberi makna pada dialog maupun monolog yang diperankannya. Dari hasil pengamatan kolaborator diperoleh data bahwa masih ada siswa yang hanya mematung ketika berdialog, baik dalam keadaan berdiri maupun duduk.

Siswa yang cukup mampu menempatkan diri di panggung dan mampu menciptakan gerakan-gerakan anggota tubuh sesuai dengan karakter ada $76 \%$. Adapun siswa yang menduduki tingkat paling tinggi dalam hal gestur, yaitu garakan tubuhnya sangat sesuai dengan karakter dan mampu menempatkan diri di panggung dengan sangat baik ada 12\%. Dari hasil pengamatan kolaborator diperoleh data bahwa tokoh "Mbah dukun Tarjo" mampu diperankan dengan ekspresi dan gestur yang sangat baik. Rata-rata nilai pencapaian kompetensi siswa dalam hal gestur adalah 75 .

Dari empat unsur yang dinilai dalam praktik bermain peran tersebut, dapat dihitung nilai rata-rata kelas. Nilai rata-rata kelas praktik bermain peran pada tindakan Siklus I adalah 75,55 . 
Berdasarkan hasil catatan lapangan, hasil penilaian, dan jawaban siswa saat refleksi diperoleh simpulan sebagai berikut.

Pada pertemuan pertama Siklus I, pada waktu melakukan permainan Joko Tingkir siswa merasa kurang bebas dalam berdiskusi, beraksi, maupun berekspresi karena permainan dilakukan di dalam kelas. Hukuman yang diberikan oleh kelompok pemenang kepada kelompok yang kalah dalam permainan Joko Tingkir terlalu umum sehingga tidak mengarah pada kompetensi bermain peran. Dalam permainan Tebak Peran siswa terlalu lama dalam menentukan action yang akan diperagakan ketika diberi kebebasan untuk menentukan sendiri. Akibatnya, waktu yang semestinya digunakan untuk berlatih tersita banyak.

Pada pertemuan kedua Siklus I, waktu yang digunakan untuk berlatih bermain peran secara berkelompok kurang longgar. Menurut pendapat siswa, anggota kelompok membutuhkan waktu untuk mempelajarai naskah terlebih dahulu sebelum membagi peran, dan berlatih.

Pada pertemuan ketiga Siklus I, praktik bermain peran kurang terasa hidup. Tidak ada bunyi-bunyian dan perlengkapan yang digunakan sehingga pementasan terasa hambar.

Pelaksanaan tindakan Siklus II terdiri atas tiga pertemuan. Pertemuan I, selama dua jam pelajaran merupakan tahap bermain dan tahap berlatih. Pertemuan II, selama dua jam pelajaran merupakan tahap berlatih lanjutan. Pertemuan III, selama tiga jam pelajaran merupakan tahap beraksi.

Pada tahap perencanaan, guru menyusun silabus dan RPP dengan menggunakan teknik learning game dengan mempertimbangkan temuan-temuan pada waktu tindakan Siklus I. Selain itu, guru menyiapkan instrumen penelitian, dan menyiapkan sarana dan media, antara lain kartu hukuman, kartu action, properti sederhana, dan alat musik.

Pada tahap implementasi tindakan pada pertemuan I, langkah-langkah yang dilakukan adalah: (1) guru melakukan apersepsi dengan bertanya jawab tentang praktik bermain peran pada Siklus I; (2) guru menyampaikan hasil refleksi dan memotivasi agar mengulangi pembelajaran bermain peran dengan rancangan baru; (3) guru memandu siswa untuk memerankan tokoh "Joko", "Ayu", dan "Banteng" dengan gerakan dan ucapan yang serentak; (4) secara berkelompok, siswa bermain permainan Joko Tingkir di luar kelas; (5) siswa bermain Tebak Peran di luar kelas; (6) siswa berdiskusi kelom- pok untuk menentukan peran, properti yang harus dipersiapkan, dan musik pengiring yang akan digunakan; dan siswa berlatih bermain peran di dalam kelas, maupun di luar kelas.

Pada pertemuan II, kegiatan yang dilakukan adalah (1) siswa dan guru bertanya jawab tentang pembelajaran pada pertemuan sebelumnya; (2) siswa meneruskan kegiatan berlatih bermain peran secara berkelompok; dan (3) siswa berlatih di halaman sekolah, aula sekolah, dan ruang karawitan.

Pada pertemuan III kegiatan yang dilakukan adalah: (1) siswa dan guru bertanya jawab tentang unsur-unsur yang dinilai dalam bermain peran; (2) siswa mempersiapkan properti dan musik pengiring yang digunakan; dan (3) siswa melakukan praktik bermain peran berkelompok secara bergantian.

Pada tahap pengamatan, kolaborator melakukan pengamatan bersamaan dengan berlangsungnya pembelajaran. Hasil pengamatan meliputi dampak tindakan terhadap proses dan hasil pembelajaran. Secara rinci, hasil tindakan tersebut dapat diuraikan sebagai berikut.

Hasil pengamatan dan evaluasi yang dilakukan oleh kolaborator dan peneliti terhadap jalannya pembelajaran pada Siklus II menunjukkan bahwa secara umum siswa sudah mampu berinteraksi dengan guru maupun dengan siswa lainnya dengan baik. Interaksi dan komunikasi tersebut terjalin dari awal hingga akhir pembelajaran, terutama pada waktu siswa berlatih bermain peran. Dari hasil catatan lapangan dua kolaborator diperoleh data bahwa ketika tahap berlatih, terjadi interaksi antara siswa satu dengan siswa lainnya berupa saling memberi saran. Selain itu, tidak segan-segan siswa bertanya kepada guru dengan pertanyaan yang beragam, antara lain tentang properti dan iringan musik yang akan digunakan. Tempat terbuka membuat siswa bebas berinteraksi dan berkomunikasi. Siswa yang minimal berkategori baik dalam hal interaksi dan komunikasi selama pembelajaran ada $97 \%$.

Berdasarkan hasil catatan lapangan kolaborator diperoleh data bahwa secara umum kerja sama siswa dalam kelompok sangat baik. Kerja sama tersebut terjadi pada awal pembelajaran hingga akhir pembelajaran, baik pada Pertemuan I, II, maupun III. Dari 34 siswa, 79\% siswa berkategori sangat baik dalam hal kerja sama dalam kelompok, 18\% siswa berkategori baik, dan hanya 3\% siswa berkategori kurang baik. Dengan demikian, siswa yang minimal berkategori 
baik dalam hal kerja sama dalam kelompok ada $97 \%$.

Dari aspek keseriusan siswa dalam mengikuti pembelajaran, secara umum siswa berdisiplin dalam mengikuti pembelajaran. Siswa mengikuti pembelajaran dengan serius dan melakukan kegiatan pembelajaran sesuai dengan perintah guru. Pada tahap bermain, semua siswa serius mengikuti jalannya permainan Joko Tingkir dan Tebak Peran.

Permainan Joko Tingkir dan Tebak Peran berjalan dengan sangat lancar karena siswa sudah paham akan permainan tersebut. Tempat pembelajaran di luar kelas membuat siswa lebih bebas dan leluasa dalam melakukan gerakan dan berbagai aktivitas permainan. Selain itu, siswa juga tampak lebih menikmati pembelajaran sehingga tidak melakukan aktivitas lain. Mereka lebih serius dalam mengikuti kegiatan pembelajaran. Dari 34 siswa, 75\% siswa berkategori sangat baik dalam hal keseriusan dalam mengikuti pembelajaran, 24\% siswa berkategori baik, dan hanya $1 \%$ siswa berkategori kurang baik. Dengan demikian, siswa yang minimal berkategori baik dalam hal keseriusan dalam mengikuti pembelajaran ada $99 \%$.

Dari data tersebut dapat disimpulkan bahwa kualitas proses pembelajaran bermain peran pada Siklus II sudah meningkat dan memenuhi kriteria keberhasilan yang telah ditentukan. Pembelajaran bermain peran dianggap berhasil jika 95\% siswa minimal berkategori baik dalam hal interaksi dan komunikasi dalam pembelajaran, kerja sama dalam kelompok, dan keseriusan dalam mengikuti pembelajaran.

Praktik bermain peran dilakukan pada pertemuan ketiga selama tiga jam pelajaran. Tiap-tiap kelompok berunjuk kerja bermain peran dengan menggunakan naskah yang sama dengan naskah yang dimainkan pada Siklus I. Akan tetapi, pada Siklus II tiap kelompok diperbolehkan menggunakan properti dan musik/bunyi-bunyian untuk mengiringi jalannya pementasan.Kelompok I memerankan naskah "Wiro dan Sableng Si Raja Gombal". Kelompok II memerankan "Bantuan Buku Bekas". Kelompok III memerankan "Kejujuran adalah Awal Kesuksesan". Kelompok IV memerankan "Akibat Perbuatan Syirik". Kelompok V memerankan "Akibat Sombong". Kelompok VI memerankan "Wewe Pencuri Kambing". Kelompok VII memerankan "Tangisan Seorang Sahabat".

Secara rinci, pada aspek vokal ada 59\% siswa yang kategori vokalnya lantang, cukup jelas sesuai dengan karakter tokoh. Bahkan,
$29 \%$ siswa vokalnya sangat lantang dan sangat jelas. Hanya empat siswa atau $12 \%$ yang vokalnya lemah dan kurang jelas ketika berdialog maupun bermonolog. Menurut hasil pengamatan kolaborator, keempat siswa tersebut memang memiliki vokal yang lemah dan memiliki rasa kurang percaya diri. Nilai rata-rata pencapaian kompetensi vokal siswa adalah 79,41.

Pada aspek intonasi, sebanyak $62 \%$ siswa telah mampu menggunakan intonasi yang bervariasi dan cukup sesuai dengan karakter ketika berdialog maupun bermonolog. Bahkan, ada 10 siswa atau $29 \%$ siswa yang intonasinya sangat bervariasi dan sesuai dengan karakter. Siswasiswa tersebut mampu menggunakan intonasi yang tepat ketika bertanya, terkejut, maupun ketika marah. Hal ini menyebabkan suasana panggung menjadi hidup. Hanya tiga siswa atau 9\% siswa yang intonasinya datar-datar saja atau kurang bervariasi. Dari catatan lapangan diperoleh hasil bahwa sebagian besar siswa mampu mengimbangi lawan bicara dalam berdialog. Mereka bertanya-jawab dengan intonasi yang bervariasi sehingga dialog terasa segar. Nilai rata-rata pencapaian kompetensi intonasi siswa adalah 80,15 .

Pada aspek ekspresi, ada 67\% siswa yang terlihat serius dalam berekspresi. Mimik mereka cukup sesuai dengan karakter. Bahkan, 24\% siswa mampu berekspresi dengan mimik yang sangat sesuai dengan karakter. Penggunaan properti sederhana dan musik menambah hidup suasana pementasan. Rasa percaya diri siswa bertambah sehingga siswa semakin berani dalam berekspresi. Namun demikian, masih ada 3 siswa atau 9\% siswa yang kurang serius dalam berekspresi. Mereka masih sering menunduk sambil tersenyum-senyum ketika berdialog meskipun tokoh yang diperankannya dalam keadaan sedih ataupun marah. Nilai rata-rata pencapaian kompetensi siswa dalam hal ekspresi adalah 78,68 .

Pada aspek gestur, hanya ada dua siswa atau 6\% dari 34 siswa yang masih kelihatan kaku dalam memainkan perannya. Mereka kurang mampu menempatkan diri di panggung. Bahkan, kadang-kadang masih membelakangi penonton. Namun demikian, secara umum siswa sudah mampu bermain peran dengan gerakangerakan anggota badan yang variatif sesuai dengan karakter tokoh yang diperankannya. Beberapa siswa mampu bergerak-gerak sesuai dengan irama musik gamelan dan kendang yang mengiringi. Properti sederhana yang digunakan juga mendukung siswa bisa ber-acting dengan gerak- 
an-gerakan yang konkret. Berdasarkan hasil pengamatan, $62 \%$ siswa atau sejumlah 21 siswa cukup mampu menempatkan diri di panggung dan mampu menciptakan gerakan-gerakan anggota tubuh sesuai dengan karakter. Nilai ratarata pencapaian kompetensi siswa dalam hal gestur adalah 81,62. Dari empat unsur yang dinilai dalam praktik bermain peran tersebut dapat dihitung nilai rata-rata kelas. Nilai ratarata kelas praktik bermain peran pada tindakan Siklus II adalah 79,97.

Hasil refleksi melalui pengisian angket tentang minat menunjukkan bahwa tidak ada satu pun siswa di kelas tersebut yang kategori minatnya sangat tinggi dan sangat rendah terhadap kegiatan bermain peran dan pembelajarannya. Ada 30 siswa atau $88 \%$ dari jumlah seluruh siswa yang minatnya tinggi dan hanya 4 siswa atau $12 \%$ dari jumlah seluruh siswa yang minatnya rendah. Berdasarkan penghitungan rata-rata skor siswa diperoleh angka 29,03. Dengan demikian, dapat disimpulkan bahwa minat siswa kelas tersebut terhadap bermain peran dan pembelajarannya termasuk kategori tinggi.

Peningkatan kualitas proses pembelajaran mulai dari pratindakan, tindakan Siklus I, dan tindakan Siklus II dapat dijelaskan sebagai berikut. Pada aspek interaksi dan komunikasi terjadi peningkatan persentase jumlah siswa yang minimal berkategori baik. Peningkatan tersebut yaitu $47 \%$ pada pratindakan meningkat menjadi $81 \%$ pada Siklus I, dan meningkat lagi menjadi 97\% pada Siklus II. Pada aspek kerja sama dalam kelompok, peningkatannya adalah $68 \%$ pada kondisi awal menjadi $94 \%$ pada Siklus I dan $97 \%$ pada Siklus II. Pada aspek keseriusan dalam pembelajaran pun terjadi peningkatan jumlah siswa yang minimal berkategori baik. Peningkatan tersebut yaitu dari $85 \%$ pada kondisi awal menjadi $88 \%$ pada Siklus I dan $99 \%$ pada Siklus II.

Setelah diterapkan teknik Learning Game, terjadi peningkatan kualitas hasil pembelajaran bermain peran. Pada aspek vokal, antara nilai rata-rata kelas pada waktu pratindakan dengan Siklus I mengalami peningkatan $21,74 \%$, antara nilai rata-rata kelas pada waktu pratindakan dengan Siklus II mengalami peningkatan $30,18 \%$. Pada aspek intonasi, antara nilai rata-rata kelas pada waktu pratindakan dengan Siklus I mengalami peningkatan $21,78 \%$, antara nilai rata-rata kelas pada waktu pratindakan dengan Siklus II mengalami peningkatan $25,23 \%$. Peningkatan juga terjadi pada aspek ekspresi dan gestur.
Nilai rata-rata ekspresi siswa pada pratindakan meningkat $20,97 \%$ pada Siklus I, dan meningkat $26,90 \%$ pada Siklus II. Nilai rata-rata gestur siswa pada pratindakan juga meningkat $17,19 \%$ pada Siklus I, dan meningkat $27,53 \%$ pada Siklus II.

Selain peningkatan kualitas proses dan hasil pembelajaran bermain peran dengan menggunakan teknik learning game, juga terjadi peningkatan minat siswa terhadap bermain peran. Pada pratindakan, masih ada $15 \%$ siswa yang kategori minatnya sangat rendah dan hanya $12 \%$ siswa yang kategori minatnya tinggi. Pada pascatindakan, tidak satu pun siswa yang kategori minatnya sangat rendah. Siswa yang kategori minatnya tinggi meningkat menjadi $88 \%$.

\section{Pembahasan}

Sebagaimana telah diuraikan, pada pratindakan minat siswa terhadap bermain peran dan pembelajarannya masih berkategori rendah. Rendahnya minat siswa tersebut berimplikasi pada rendahnya kualitas proses pembelajaran dan rendahnya kualitas hasil pembelajaran. Pembelajaran belum berjalan dengan baik. Strategi pembelajaran yang diterapkan guru belum mampu membuat siswa nyaman dan senang dalam belajar. Sebagian besar siswa kurang percaya diri dan beranggapan bahwa bermain peran itu sulit. Akibatnya, kompetensi bermain peran siswa pun rendah.

Hasil angket menunjukkan bahwa 68\% siswa tidak setuju terhadap pernyataan "Saya suka akan pembelajaran bermain peran". Hal ini berarti sebagian besar siswa tidak suka akan pembelajaran bermain peran. Hasil angket yang lain menunjukkan bahwa $85 \%$ siswa tidak setuju terhadap pernyataan "Bagi saya, pembelajaran bermain peran menyenangkan". Hal ini berarti sebagian besar siswa beranggapan bahwa pembelajaran bermain peran itu tidak menyenangkan. Dari kedua hasil angket tersebut dapat disimpulkan bahwa sebagian besar siswa tidak suka akan pembelajaran bermain peran karena strategi pembelajaran yang diterapkan guru kurang menyenangkan.

Berdasarkan hasil pengamatan diperoleh data tentang kualitas proses pembelajaran. Proses pembelajaran dianggap berkualitas apabila 95\% siswa minimal berkategori baik dalam ketiga aspek yang dinilai, yaitu interaksi dan komunikasi dalam pembelajaran, kerja sama dalam kelompok, dan keseriusan dalam mengikuti pembelajaran. Pada tahap pratindakan ada 53\% siswa yang bersikap pasif, tidak pernah bertanya 
dan menjawab pertanyaan guru ataupun sesama siswa. Dalam diskusi kelompok, ada $32 \%$ siswa yang hanya diam, tidak punya ide, tidak menghargai teman, dan tidak berperan sama sekali. Selain itu, masih ada 15\% siswa yang kurang disiplin dan kurang serius dalam mengikuti pembelajaran. Kesimpulannya, kualitas proses pembelajaran masih kurang sesuai dengan harapan ideal peneliti dan kolaborator.

Keterampilan siswa dalam bermain peran pada pratindakan dilihat dari nilai rata-rata, kompetensi vokal 61, intonasi 64, ekspresi 62, dan gestur 64. Nilai rata-rata dari keempat unsur tersebut adalah 62,75 . Nilai tersebut masih jauh dari kriteria ketentuan minimal, yaitu 70,00. Dengan demikian, dapat disimpulkan bahwa kualitas keterampilan siswa dalam bermain peran pada pratindakan masih rendah. Rendahnya kualitas bermain peran siswa pada pratindakan ini disebabkan minat siswa terhadap pembelajaran rendah. Penyebab rendahnya minat siswa adalah strategi pembelajaran yang diterapkan guru kurang tepat dan kurang menyenangkan.

Strategi pembelajaran yang dianggap mampu meningkatkan minat siswa terhadap bermain peran dan pembelajarannya adalah pembelajaran dengan teknik learning game. Dengan permainan Joko Tingkir dan permainan Tebak Peran, diharapkan kualitas proses dan hasil pembelajaran meningkat karena pembelajaran dikemas dalam bentuk permainan yang menyenangkan.

Penelitian tindakan kelas dalam pembelajaran bermain peran dengan teknik learning game telah dilaksanakan dalam dua siklus. Setiap siklusnya terdiri atas tiga kali pertemuan. Adapun rangkaian kegiatan setiap siklus terdiri atas tiga tahap kegiatan, yaitu tahap bermain, berlatih, dan beraksi.

Pada tahap bermain, siswa diajak bermain permainan Joko Tingkir dan permainan Tebak Peran. Pada tahap berlatih, siswa berlatih bermain peran secara berkelompok dengan menggunakan naskah yang ditulis siswa sendiri sesuai dengan tuntutan kurikulum. Pada tahap beraksi, setiap kelompok berunjuk kerja bermain peran di depan kelas secara bergantian. Kelompok yang tidak sedang tampil diminta ikut mengamati dan membuat catatan-catatan yang berisi komentar terhadap aksi bermain peran kelompok lain yang sedang tampil.

Berdasarkan hasil pengamatan, ketiga tahap kegiatan yang telah diuraikan dapat terlaksana dengan baik. Berbagai aktivitas dalam pembelajaran bermain peran dengan teknik learning game dari Siklus I hingga Siklus II menunjukkan adanya peningkatan.

Pelaksanaan siklus I dimulai dengan perlakuan tindakan berupa permainan. Permainan pertama adalah Joko Tingkir dengan model bertanding menggunakan tokoh Joko, Ayu, dan Banteng. Kelompok kalah diberi hukuman. Permainan kedua adalah Tebak Peran, yakni salah satu kelompok memperagakan peran tertentu, kelompok lain menebak peran tersebut. Pembelajaran diteruskan dengan kegiatan berlatih bermain peran secara berkelompok berdasarkan naskah yang telah ditulis oleh siswa dan dilanjutkan dengan beraksi bermain peran di depan kelas. Berdasarkan hasil pengamatan, proses pembelajaran menjadi lebih baik setelah diberi perlakuan tindakan berupa pembelajaran dengan teknik learning game. Siswa tampak lebih aktif terlibat dalam pembelajaran. Interaksi dan komunikasi antarsiswa dan antara siswa dan guru semakin terjalin dengan baik. Kerja sama siswa dalam kelompok pun semakin baik. Pada tindakan Siklus I, siswa tampak lebih serius dalam mengikuti pembelajaran dibandingkan dengan pada waktu pratindakan. Kemampuan vokal, intonasi, ekspresi, dan gestur siswa dalam bermain peran pada Siklus I lebih baik dibandingkan waktu pratindakan. Siswa sudah mampu menghayati karakter tokoh dan berekspresi dengan baik. Vokal dan intonasi siswa dalam berdialog maupun bermonolog pun semakin jelas dan bervariasi. Dalam hal ini, teori konstruktivisme yang digunakan dalam penelitian ini telah terbukti kebenarannya. Pengetahuan dan keterampilan siswa dalam bermain peran dibangun sedikit demi sedikit melalui tahapantahapan kegiatan yang sederhana berupa permainan Joko Tingkir dan permainan Tebak Peran. Selain itu, terciptanya suasana kegembiraan dalam pembelajaran melalui permainan tersebut juga menimbulkan sugesti positif terhadap keberhasilan proses dan hasil pembelajaran. Hal ini sesuai dengan teori suggestology dan teori pembelajaran PAIKEM yang digunakan dalam penelitian ini.

Pelaksanaan Siklus II lebih difokuskan pada perbaikan dari hasil refleksi Siklus I. Permainan Joko Tingkir yang dilakukan di luar kelas membuat siswa lebih bebas dan berani dalam bermain dan berlatih. Terjadi peningkatan kreativitas siswa dalam beraksi dan berekspresi. Penggunaan kartu hukuman yang sudah dipersiapkan guru dalam permainan Joko Tingkir membuat hukuman lebih terarah sehingga tidak terlepas dari kompetensi yang diperlukan dalam 
bermain peran. Selain itu, jenis action yang sudah ditentukan guru dalam permainan Tebak Peran membuat siswa dapat langsung berlatih action tersebut tanpa harus kehilangkan waktu untuk berdiskusi menentukan action yang akan diperagakan. Kualitas bermain peran siswa lebih baik karena siswa diberi waktu yang cukup longgar untuk berlatih. Selain itu, penggunaan alat musik gamelan dan properti sederhana juga mampu meningkatkan kualitas proses dan hasil pembelajaran. Dengan demikian, perlakuan tindakan dalam pembelajaran bermain peran dengan teknik learning game pada Siklus II telah mampu meningkatkan kualitas proses dan hasil pembelajaran. Pembelajaran berjalan lebih terarah dan lebih hidup. Keterampilan siswa dalam bermain peran yang meliputi vokal, intonasi, ekspresi, dan gestur pun lebih baik dibandingkan dengan siklus sebelumnya.

Jadi, pelaksanaan pembelajaran dengan teknik learning game dari siklus satu ke siklus berikutnya telah mampu mengatasi masalah yang terjadi dalam pembelajaran bermain peran selama ini.

Penilaian kualitas proses pembelajaran dalam penelitian ini dilakukan dengan mengamati tiga aspek penilaian yang telah ditentukan, yaitu (1) interaksi dan komunikasi siswa, (2) kerja sama siswa dalam kelompok, dan (3) keseriusan siswa dalam mengikuti pembelajaran. Kriteria keberhasilan tindakan terhadap proses pembelajaran yang telah ditentukan adalah jika 95\% siswa minimal berkategori baik dalam ketiga aspek penilaian tersebut. Peningkatan kualitas proses pembela-jaran dapat dilihat pada diagram berikut.

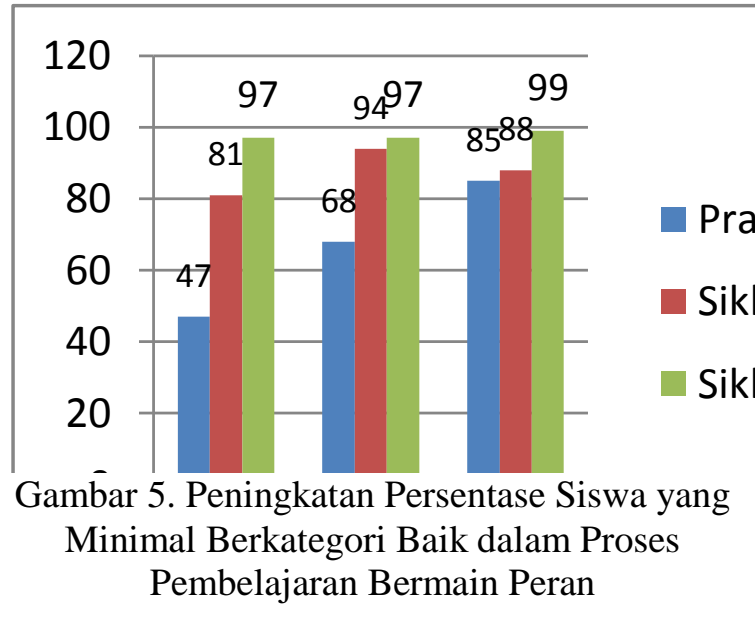

Dari diagram tersebut dapat diketahui adanya peningkatan kualitas proses pembelajaran pada waktu pratindakan, tindakan Siklus I, dan tindakan Siklus II. Pada aspek 1 terjadi peningkatan persentase jumlah siswa yang minimal berkategori baik. Peningkatan tersebut adalah dari $47 \%$ pada pratindakan menjadi $81 \%$ pada Siklus I dan 97\% pada Siklus II. Pada aspek 2, persentase jumlah siswa yang minimal berkategori baik juga mengalami peningkatan. Peningkatan tersebut adalah dari $68 \%$ pada pratindakan menjadi $94 \%$ pada Siklus I dan $97 \%$ pada Siklus II. Pada aspek 3, peningkatan terjadi dari $85 \%$ pada pratindakan menjadi $88 \%$ pada Siklus I dan $99 \%$ pada Siklus II. Dengan demikian, pada tindakan Siklus II kualitas proses pembelajaran dapat mencapai target keberhasilan sesuai dengan kriteria yang telah dirumuskan dalam penelitian ini, yaitu 95\% siswa minimal berkategori baik.

Penilaian kualitas hasil pembelajaran dilakukan dengan mengamati unjuk kerja siswa dalam bermain peran. Adapun unsur yang dinilai meliputi keterampilan siswa dalam hal vokal, intonasi, ekspresi, dan gestur. Kriteria keberhasilan tindakan terhadap hasil pembelajaran yang telah ditentukan dalam penelitian ini adalah jika terjadi peningkatan nilai rata-rata kelas sebesar minimal $25 \%$ antara sebelum tindakan dengan sesudah tindakan. Sebelum mengetahui persentase peningkatan antara pratindakan dengan Siklus I dan dengan Siklus II, berikut ini ditampilkan diagram peningkatan nilai rata-rata kelas dari keempat unsur tersebut.

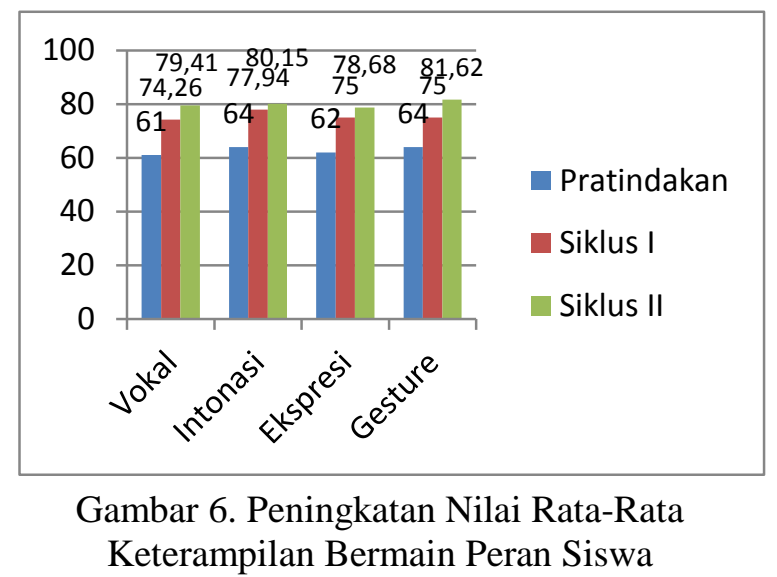

Dari diagram tersebut dapat diketahui adanya peningkatan nilai rata-rata siswa dalam bermain peran yang meliputi empat unsur penilaian. Pada unsur vokal, peningkatannya adalah dari 61 pada pratindakan meningkat menjadi 74,26 pada Siklus I dan 79,41 pada Siklus II. Pada unsur intonasi, peningkatannya adalah dari 64 pada pratindakan meningkat menjadi 77,94 pada Siklus I dan 80,15 pada Siklus II. Pada unsur ekspresi, peningkatannya adalah dari 62 pada pratindakan meningkat menjadi 75 pada 
Siklus I dan 78,68 pada Siklus II. Pada unsur gestur, peningkatannya adalah dari 64 pada pratindakan meningkat menjadi 75 pada Siklus I dan 81,62 pada Siklus II.

Selain peningkatan kualitas proses dan hasil pembelajaran, juga terjadi peningkatan minat siswa terhadap bermain peran dan pembelajarannya. Pada pratindakan, masih ada $15 \%$ siswa yang minatnya sangat rendah, $73 \%$ siswa minatnya rendah, dan hanya ada $12 \%$ siswa yang minatnya tinggi. Pada pascatindakan, tak ada satu pun siswa yang minatnya sangat rendah, hanya ada $12 \%$ siswa yang minatnya rendah, dan siswa yang minatnya tinggi meningkat menjadi $88 \%$. Dengan demikian, dapat disimpulkan bahwa setelah dilakukan tindakan berupa teknik learning game dalam pembelajaran bermain peran, minat siswa terhadap bermain peran dan pembelajarannya meningkat.

\section{SIMPULAN}

Berdasarkan rumusan masalah, hasil penelitian, dan pembahasan dapat ditarik simpulan sebagai berikut.

Pertama, teknik Learning Game dalam pembelajaran bermain peran dilaksanakan dengan dua jenis permainan, yakni permainan Joko Tingkir dan Tebak Peran. Kedua permainan dalam teknik learning game ini digunakan sebagai sarana untuk mencapai tujuan, yakni untuk meningkatkan kualitas proses dan hasil pembelajaran bermain peran.

Kedua, teknik Learning Game dalam pembelajaran bermain peran dapat meningkatkan kualitas proses pembelajaran. Peningkatan kualitas proses pembelajaran dapat dilihat dari peningkatan persentase jumlah siswa yang minimal berkategori baik dalam aspek interaksi dan komunikasi, kerja sama, dan keseriusan siswa dalam mengikuti pembelajaran.

Ketiga, teknik Learning Game dalam pembelajaran bermain peran juga dapat meningkatkan kualitas hasil pembelajaran. Peningkatan tersebut dapat dilihat dari persentase peningkatan nilai rata-rata unjuk kerja siswa dalam bermain peran pada pratindakan dan pascatindakan. Aspek yang dinilai meliputi keterampilan siswa dalam hal vokal, intonasi, ekspresi, dan gestur.

Implikasi setelah dilakukan penelitian ini adalah siswa bertambah senang dan percaya diri dalam mengikuti pembelajaran bahasa Indonesia, khususnya kompetensi yang berupa unjuk kerja. Minat siswa terhadap bermain peran pun meningkat. Hal ini dibuktikan dengan adanya beberapa kelas yang memilih menampilkan seni bermain peran pada acara pentas seni dalam rangka perpisahan kelas IX daripada seni lainnya.

Selain berimplikasi pada siswa, penelitian ini juga berimplikasi pada guru. Guru dan kolaborator melanjutkan penggunaan teknik Learning Game pada pembelajaran bermain peran untuk waktu-waktu berikutnya. Selain itu, melalui forum MGMP (Musyawarah Guru Mata Pelajaran), peneliti telah menginformasikan kepada guru bahasa Indonesia tentang teknik Learning Game sebagai salah satu strategi yang digunakan dalam pembelajaran bermain peran. Beberapa guru mata pelajaran lain di sekolah tempat berlangsungnya penelitian ini juga termotivasi untuk melakukan penelitian tindakan kelas dengan menerapkan strategi pembelajaran yang kreatif, inovatif, dan menyenangkan seperti halnya teknik Learning Game.

Berdasarkan simpulan yang telah dikemukakan dalam penelitian ini, dapatlah dikemukakan saran: (1) guru Bahasa Indonesia di sekolah lain yang memiliki permasalahan yang sama, perlu menerapkan teknik Learning Game dalam pembelajaran bermain peran; (2) kompetensi yang telah dimiliki hendaklah dikembangkan, baik melalui kegiatan ekstra-kurikuler di sekolah maupun kegiatan lain di luar sekolah; (3) sekolah perlu memberikan motivasi, pendanaan, dan penyelenggaraan workshop peningkatan kualitas pembelajaran bagi seluruh guru agar mau dan mampu mengembangkan teknik pembelajaran inovatif; dan (4) diharapkan penelitian ini dapat dijadikan sumber inspirasi maupun referensi bagi peneliti-peneliti berikutnya.

\section{DAFTAR PUSTAKA}

Ardiana, Leo Idra. (2003). Penelitian tindakan kelas. Jakarta: Departemen Pendidikan Nasional, Direktorat Jenderal Pendidikan Dasar dan Menengah, Direktorat Pendidikan Menengah Pertama.

Baldwin, P. \& K. Fleming. (2003). Teaching literacy through drama: Creative approaches. New Fetter Lane, London: RoutledgeFalmer.

Brown, H. D. (2001). Teaching by principles, An interactive approach to language pedagogy, Second edition. San Francisco: Addison Wesley Longman Inc.

Depdiknas. (2003). Pendekatan kontekstual. Jakarta: Direktorat Jenderal Pendidikan 
Dasar dan Menengah, Direktorat Pendidikan Menengah Pertama.

DePorter, B. \& M. Hernacki. (2005). Quantum learning. (Terjemahan Alwiyah Abdurrahman). Bandung: Kaifa.

Dewojati, Cahyaningrum. (2010). Drama, sejarah, teori, dan penerapannya. Yogyakarta: Gadjah Mada University Press.

Endraswara, Suwardi. (2003). Membaca, menulis, mengajarkan sastra, sastra berbasis kompetensi. Yogyakarta: Kota Kembang.

Kemendiknas. (2011). PAIKEM, Pembelajaran aktif, inovatif, kreatif, efektif, dan menyenangkan. Jakarta: Pusat Pengembangan Tenaga Kependidikan, Badan Pengembangan SDM dan Penjaminan Mutu Pendidikan.

Meier, D. (2005). The accelerated learning handbook. (Terjemahan Rahmani
Astuti). Bandung: Kaifa, PT Mizan Pustaka.

Monkks, F.J. et al. (1992). Psikologi perkembangan-Pengantar dalam berbagai bagiannya. Yogyakarta: Gadjah Mada University Press.

Rahmanto, B. (1988). Metode pengajaran sastra. Yogyakarta: Kanisius.

Republika Online. (2009). "Casting terbuka film Dalam Mihrab Cinta. 24 Desember 2009. Diambil pada tanggal 15 Agustus 2010 dari http://www.republika.co.id

Sofyan, Eko Hendrawan. (23 Desember 2009). Proses casting film $K C B$ dimulai. Artikel. Diambil pada tanggal 22 September 2010 dari http://www.kompas.com

Zamroni. (2003). Paradigma pendidikan masa depan. Yogyakarta: BIGRAF Publishing. 